Zdenka Kádeková

Ludmila Nagyová

Elena Horská

\title{
1.4. ROLE OF PUBLIC RELATIONS IN THE SUSTAINABILITY MARKETING IN THE SLOVAK AGRIBUSINESS PRACTICE
}

\begin{abstract}
Summary
The paper points at importance of Public Relations and its role in the sustainability marketing in the Slovak agribusiness practice. Strategically, the business must be centered on the customers more than the products. Public Relations help the companies target more on consumer's needs. If the companies push more on the product and disregard consumers wants and the benefits they can get, company will lose the customers in no time.

Paper shows the selected successful stories of sustainability marketing in agribusiness in Slovakia and most popular types of PR - events and frequencies of their organizing in the agricultural companies with foreign participation and domestic ones as well as importance of using media for promotion. When reaching sustainability and business success, there are certain requirements that have to be met. In the business, the four Ps are used together with some more innovative solutions and approaches as public, politics, and some other external and internal factors. In addition to those factors there are in the paper shown certain requirements that have to be met in order to be successful in responsible business, marked with $\mathrm{S}$ as satisfaction, safety and sustainability are.
\end{abstract}

Keywords: sustainability marketing, Public Relations, events, media, agribusiness in Slovakia

\section{Introduction}

Marketing plays a great role in today's life. It includes the wide range of activities involved in making sure that companies are continuing to meet the needs of the customers. Thanks to marketing companies build the strong customer relationships and create value for their customers and for themselves. Marketing is the art and science of influencing consumer behaviour. Every aspect of marketing is inseparably tied to consumer psychology. From advertising and promotions to public relations, pricing and packaging, marketing strategies are designed with one purpose in mind: encourage habitual purchases. Understanding marketing and its important role in consumer behaviour is just as valuable to consumers in the marketplace as it is to business owners. Marketing is perhaps the most important activity in a business because it has a direct effect on profitability and sales. Marketing is a very important aspect in business since it contributes greatly to the success of the organization that covers advertising, promotions, public relations, and sales (Horská et al., 2011)

It is the process of introducing and promoting the product or service into the market and encourages sales from the buying public. Since the goal of marketing is to make the product or service widely known and recognized to the market, marketers must be creative in their marketing activities. In this competitive nature of many businesses, 
getting the product noticed is not that easy. Strategically, the business must be centered on the customers more than the products (Kibicová, 2007).

Public Relations help the companies target more on consumers needs. If the companies push more on the product and disregard consumers' wants and the benefits they can get, company will lose the customers in no time. The sad thing is that getting them back is the hardest part. Storytelling has always been used to sell products and services, but messages that are more positive will yield better results when it comes to sustainability. Telling stories is just great for sustainability marketing. Companies have used story power to remember, entertain and persuade. Stories engage senses of customers, their fuel is emotion and the journey they take them on is measured in feelings and business success. Research has shown that threats - often used in areas such as climate change and safety ads - can instead of success cause resistance. Making customers feel bad about their lifestyle will not make them to change it. Instead they will probably like the company less and stop reading the story. Nike's Makers campaign is one example of where a strong sense of story helps the viewer believe in a solution the company has come up with. Rainforest Alliance's Follow the Frog video uses humour to deliver its message. These videos follow the advice "never put your story, your brand, or your product in the negative space“". Especially if you want to change behaviours such as sustainability. Some great clues for successful storytelling for sustainability are as follows:

- Make people feel empowered, not guilty. Steer a wide berth around using inadequacy to promote sustainable behaviour.

- Cast people in the story as the hero-in-waiting. Help people to live the experience, but show them they are on the winning team.

- Help them to believe in the solution. Unite them with the other solvers. Show them where they have won before.

- Use metaphor and analogy to explain complex information to people, and make that metaphor relevant to them and their life (or job).

- Entertain, surprise, amuse, take people on a journey. Do not ever bore them. (Benett, 2013)

Marketers, as communicators and influencers of culture, are in a privileged position to make a difference to their companies' 'triple bottom line'. However, marketing departments have traditionally been quite reluctant to integrate CSR and sustainability agendas into their work.

Research showed that:

- $22 \%$ of German and Spanish people take environmental aspects of products into account when shopping.

- in the UK, ethical consumer spending grew more than threefold between 1999 and 2006, from 9.6 to 32.2 billion GB£

- in France, $83 \%$ of consumers approve of no longer using plastic bags in retail shops. (CSR Europe, 2013)

More and more consumers wish to reduce their environmental footprint, but to make this a reality consumption habits must change.

Marketers, as communicators and influencers of culture, are in a privileged position to make a difference to their companies' "triple bottom line". However, marketing 
departments have traditionally been quite reluctant to integrate CSR and sustainability agendas into their work. (Ries and Ries, 2009)

Sustainable marketing is the process of promoting products that are environmentally safe at the retail level and touting a company's commitment to sustainable practices at the public relations level. It applies traditional marketing techniques but in a specific context.

Sustainability marketing integrates social and ecological criteria into the whole process of marketing. The conception of sustainability marketing consists of six steps: analysis of socio-ecological problems, analysis of consumer behaviour, normative sustainability marketing, strategic sustainability marketing, instrumental sustainability marketing and transformational sustainability marketing. (Belz and Birte, 2005; Belz, 2005)

1. Step: Analysis of the social and ecological problems, generally and specifically with respect to products which satisfy customer needs and wants.

2. Step: Analysis of consumer behaviour with special respect to social and ecological concerns.

3. Step: Corporate commitments to sustainable development in the mission statement, development of sustainability visions, formulation of sustainable principles and guidelines, setting of socio-ecological marketing objectives and goals (normative aspects of sustainability marketing).

4. Step: Socio-ecological product quality as well as sustainability segmentation, targeting, positioning, and timing of market entry (strategic aspects of sustainability marketing).

5. Step: Integration of social and ecological criteria into the marketing-mix, i.e. products, services and brands, pricing, distribution and communication (instrumental aspects of sustainability marketing).

6. Step: Participation in public and political change processes, which transform existing institutions towards sustainability (transformational aspects of sustainability marketing).

In which way does sustainable development change the nature of marketing? What is distinctive about sustainability marketing? There are at least six distinguishing features of the sustainability marketing concept (Belz, 2005):

1. Ecological and social problems: In conventional marketing literature, the ecological and social problems of products along the whole life cycle are hardly considered. Therefore, the analysis remains on a rather superficial level. Usually, the situation of the natural environment is briefly analysed as part of the macro environment of the company. The shortages of raw materials and increased pollution are mentioned without any further consequences for the conception of marketing. (Kotler and Armstrong, 2004; Peattie, 1999) In contrast, the analysis and identification of ecological and social problems are points of departure in sustainability marketing.

2. Intersection: The identification of the intersection between socio-ecological problems and consumer behaviour is crucial for sustainability marketing. Social activists with big hearts put a strong emphasis on the solution of socio-ecological problems, but widely neglect consumer wants and demand. They follow a kind of antimarketing or alternative marketing approach. Mainstream marketing mainly focuses on 
consumer demand overlooking the social and ecological environments. Sustainability marketing tries to find solutions to the socio-ecological problems and at the same time meet customers demand.

3. Normative aspects: In conventional marketing, the long-term aim is the building of profitable customer relationships. Traditional marketing goals are increases in sales, profits and market shares. In contrast, sustainability marketing aims at sustainable and profitable relationships with customers, the natural environment and the social environment, thus meeting the triple top line. Besides common marketing goals like sales, market shares and profits, ecological and social objectives are also important. Furthermore, sustainability marketing critically questions underlying assumptions and reflects key concepts of marketing (e.g. needs, wants, and consumer sovereignty).

4. Information asymmetries: Social and ecological qualities of products are often credence qualities (e.g. organic farming or fair trade products). The customer has to believe the information given by producers or third parties with respect to the social and ecological qualities of products. These kinds of information asymmetries open the door for opportunistic behaviour on the supply side, which may lead to scepticism on the demand side and, finally, to non-purchases and market failure. That is why signalling, credibility and trust are crucial in sustainability marketing.

5. Time aspects: Classical marketing is focussed on sales and transactions. It is rather short-term oriented and has a bias towards the present. Modern marketing represents a paradigm shift from transactions towards relations. That is why it is called "relationship marketing". (Christopher et al., 1991) It aims at building lasting customer relationships in order to produce high customer equity. Sustainability marketing goes much further. It aims at building lasting relationships with customers, the social environment and the natural environment. Thus, long-term thinking and futurity are fundamental components of sustainability marketing.(Peattie, 1999)

6. Transformational aspects: In conventional marketing, the macro environment is often taken for granted. Many companies regard external forces as uncontrollable elements they have to adapt to. In sustainability marketing, the macro environment is perceived as a constraint to overcome. Within the existing framework, there are few economic incentives to behave in a sustainable way, both for producers and for consumers. To change the existing frameworks in favour of sustainability, common efforts of governments, non-governmental organizations and companies are necessary, on local, national and international levels. (Kotler and Armstrong, 2004)

To implement the sustainability marketing strategies, an instrumental sustainability marketing (ISM) has to be developed, i.e. a comprehensive marketing-mix, which integrates social and ecological criteria. The sustainability marketing-mix includes sustainable products, services and brands; suitable and fair pricing; multi-channel distribution and credible communication between information and animation. (Belz and Birte, 2005)

Quite often, the marketing-mix is reduced to the fourth " $p$ " - communication - but without an innovative sustainable product, attractive and fair prices as well as an effortless access to those products the sustainability marketing-mix would not be complete. Nevertheless, it is the bilateral communication between the company and its current and prospective customers, which builds and maintains any kind of 
relationship, which again constitute the core of sustainability marketing. In general, the communications mix is composed of a specific combination of advertising, sales promotion, public relations, personal selling and direct-marketing tools in order to achieve the marketing objectives. (Kotler and Armstrong, 2004)

When talking about sustainability marketing, marketing mix, consisting of 4Ps: Product, Price, Place and Promotion has to work for 3Ps: People, Planet and Profit (Corporate Social Responsibility). There is an opportunity now for marketers to be at the heart of the Triple Bottom Line process where, alongside the normal financial bottom line, business is also required to think about both its environmental and social impacts, creating a complex arrangement of bottom-line deliverables. The customers who are driving the demand for companies to be more accountable and marketers are at the front line building relationships with these customers, identifying with them. Putting them in a strong position to take this customer insight to the rest of the company. Marketers impact on those areas critical to engagement with sustainability processing, packaging and distributing a product. Their communication skills keep the customer and the rest of the company informed on the viability of sustainability practices. (Ábelová and Kádeková, 2011)

Companies who do not understand that CSR is about business sustainability and integrity as much as it is about social programs, often make the mistake of making CSR a marketing or PR program/problem. By doing so they essentially "green-wash" their company. In my opinion, PR should lightly handle CSR initiatives until the CSR program has momentum and there is something to actually celebrate and brag about. Celebrating decency and expected behaviour is not good PR on CSR. It is artificial and could cause more harm than good. PR should let the public know that there is a CSR program, that there will be a report, and what some of the programs are that are under development, or highlight ongoing/historical CSR efforts. (Rochte, 2009)

Following this trend, also the agribusinesses in Slovakia use the new forms of addressing customer. (Kleinová and Ürgeová, 2011) Only by using this way can be successful. Customers appreciate when a company from which they buy goods prefers green marketing and social corporate responsibility. However, people need to be informed about this. (Gaspariková and Nagyová, 2010)

The communication via advertising is not as effective, as everyone is exposed to several hundreds of advertising messages every day and this makes people bored. Marketers simply need to evaluate and consider new methods of obtaining customer focus, which is also a major challenge. (Horská and Ürgeová, 2009) The most important moment is therefore to find new ways and means to strengthen brand in people's minds. PR has an increasing role in the marketing mix, which builds and strengthens the brand of company without negative secondary effects that so often accompanies the ads. (Wells et al., 2002)

The problem is that marketers have created a position to think about the most effective communication mix and continue their habits even though the evidence speak against and also demonstrates the loss of efficiency. If there would be only a few TV stations, radio stations and newspapers, mass marketing would be very effective also in the way of supporting sustainability marketing. As the country has dozens of TV and radio stations is very expensive to reach a mass audience. The increasing 
fragmentation of media audiences requires marketers to engage more targets into smaller groups, even on a one-to-one marketing. This will reduce the cost of promotion. (Horská et al., 2010) The great way how to reach the success is using Public Relations. Until now, the role of Public Relations was underestimated in Slovakia. Public Relations consist of several instruments: publishing, events promotional events, news, retraction of community, identity formation, lobbying, and other social investments. PR has a better chance to elbow his way through the crowded communications and is much easier to break the communication gap. (Kubicová and Kádeková, 2011) What is more, the message may be more appropriate and credible. Public relations is the right tool to attract attention and motivate people not only to buy the product from the reliable company with a trustworthy name but also make them to change the behaviour in the meaning of sustainable marketing. (Kretter, 2010)

\section{Material and methods}

There is 219 agribusinesses registered is in the Business Register of Slovakia, with 20 or more employees and annual sales of own products and goods 5 million Euros and more. This number includes food-manufacturing companies, except companies with the production of tobacco products. Total number of agribusinesses in Slovakia divided by their legal forms, such as cooperatives, partnerships, legal persons and selfemployed persons are not registered in the Business Register, their estimated number is 5221 .

Within our research was asked 219 agribusinesses to fill out the questionnaire. Representativeness of this sample group was tested by the Chi-square test ( $\chi 2$ test) which is based on a comparison of empirical and theoretical frequencies for each category of observed characters. Test criterion assumes independence between quality characteristics using the following relations $(1,2)$ :

$\chi^{2}=\sum_{i=1}^{r} \sum_{j=1}^{c} \frac{\left(O_{i j}-E_{i j}\right)^{2}}{E_{i j}}$

$E_{i j}=\frac{\left(R_{i}\right) *\left(C_{j}\right)}{n}$

where:

Oij- empirical abundance in the cell in the $i$-th row and $j$-th column

Eij- theoretical abundance in the cell in the $i$-th row and $j$-th column

r- number of categories first (line feed) character

$\mathrm{c}$-number of other categories (the bar) character

$\mathrm{Ri}$ - sum of frequencies in the i-th row

$\mathrm{Cj}$-sum of frequencies in the $\mathrm{j}$-th column

$\mathrm{n}$ - the total number of respondents 
HO (null hypothesis) implies the absence of dependence (association) between selected quantitative traits. Alternative hypothesis $H 1$ states that there exists dependence between characters:

HO: The row and column variables are independent.

H1: Row and column variables are dependent.

Calculated $\chi^{2}$ test criterion is compared with the tabulated values or $p$-value is compared to the level of significance $\alpha$. If the p-value (the theoretical significance level) <alpha (0.05), we can say that between the row and column variables exists dependence.

In the paper was used also the association and contingency analysis by exploring the relationships and dependencies between the quality characteristics. Association examines the relationship between alternative characters with two variations, examines the relationship between contingency characters with more variations. At the beginning of the analysis are sorted input data and classification results are presented in contingency tables.

Frequency table shows the frequency distribution of values of one variable and then provides a breakdown of the categorical variable or numeric variable divided into categories. The table contains the absolute and relative frequencies. Frequency tables reveal defects that could significantly subsequent statistical analysis discarded. Contingency table shows the frequency distribution of two categorical variables.

\section{Results and Discussion}

Table 1 shows the result of Chi-square test. Based on a comparison of the calculated values of the test criteria and tabulated values do not reject the null hypothesis, the sample group of agribusiness companies is representative on the significance level alpha of 0.01 .

Table 1: Results of $\chi^{2}$ Test by Categories of Agribusiness Production

\begin{tabular}{|l|r|l|l|}
\hline \multicolumn{1}{|c|}{$\begin{array}{c}\text { Categories of } \\
\text { Production }\end{array}$} & \multicolumn{1}{|c|}{ Result of Test } & \\
\hline Alcohol & 25 & Calculated value & $\mathbf{1 6 . 0 6 9 0 6}$ \\
\hline Meat & 54 & Tabulated value & $\mathbf{1 6 . 8 1 1 8 9}$ \\
\hline Vegetable & 26 & & \\
\hline Bread & 61 & & \\
\cline { 1 - 2 } Non alcoholic beverages & 17 & & \\
\cline { 1 - 2 } Milk & 23 & & \\
\hline Sweets & 13 & & \\
\hline Total & $\mathbf{2 1 9}$ & & \\
\hline
\end{tabular}

Source: VUEPP, own calculations, XLSTAT

To follow the PR activities of individual agribusinesses and then to quantify their spending on PR activities is quite difficult, that is the reason we have chosen firstly to list top PR agencies in Slovakia divided by Incomes from PR activities in the year 2012 (Table 2). 
Kádeková, Z. - Nagyová, L. - Horská, E.

Table 2: TOP 10 PR Agencies by incomes for PR activities in Slovakia (in 2012)

\begin{tabular}{|c|c|c|}
\hline Order & TOP PR Agencies & Amount in EUR \\
\hline 1. & Seesame Communication Experts (Apr Sr) & 1643000 \\
\hline 2. & Neopublic Porter Novelli (Apr Sr, Ipra) & 987178 \\
\hline 3. & Dynamic Relations 2000 & 973000 \\
\hline 4. & Ami Communications Slovakia (Apr Sr) & 712900 \\
\hline 5. & Prime Time (Apr Sr) & 567000 \\
\hline 6. & Comm & 321020 \\
\hline 7. & Snowball & 312600 \\
\hline 8. & Vyv Pr & 296755 \\
\hline 9. & Media \& Communication Consulting (Apr Sr) & 225987 \\
\hline 10. & Arthur Media & 201345 \\
\hline
\end{tabular}

Source: Strategies. HN online. Authors own research.

TOP 10 leading PR agencies in Slovakia stated that their most important clients from the agribusiness are Nestle Slovakia, Unilever Slovakia, Danone Slovakia, CocaCola Slovakia, Wrigley, Slovakia Chips, Dr. Oetker, Heineken, Kofola, Hubert J.E., Slovakia Chips, Hyza, McCain, Penam, Topvar, Becherovka, Pepsi-Cola SR, Hame Slovakia, Teekanne (Table 3).

Table 3: TOP Clients of PR Agencies in Slovakia ( year 2012)

\begin{tabular}{|c|}
\hline TOP Clients of PR Agencies in SR \\
\hline Nestle Slovakia \\
\hline Unilever Slovakia \\
\hline Danone Slovakia \\
\hline Coca-Cola Slovakia \\
\hline Wrigley \\
\hline Slovakia Chips \\
\hline Dr. Oetker \\
\hline Heineken \\
\hline Kofola \\
\hline Hubert J.E. \\
\hline Slovakia Chips \\
\hline Hyza \\
\hline McCain \\
\hline Penam \\
\hline Topvar \\
\hline Becherovka \\
\hline Pepsi-Cola Sr \\
\hline Hame Slovakia \\
\hline Teekanne \\
\hline Source: Own Research \\
\hline
\end{tabular}


Agribusinesses listed in Table 3, significantly contribute to incomes of top PR agencies, in average from 30 to $40 \%$, the rest represents income from the businesses from other areas.

Large companies realize the importance of PR tools and use it together with traditional forms of reaching the customer, which is a very positive phenomenon.

Events organizing is one of the most popular forms of reaching the customer. Therefore, we focused on the analysis of events in the use of domestic enterprises and enterprises with foreign participation. $75 \%$ of the analyzed companies had a purely domestic participation, the remaining $25 \%$ were companies with foreign participation.

Results of Chi-square test ( $\chi 2$ test) confirmed statistically significant differences in the method of organizing events for the analyzed categories of companies - domestic versus foreign invested enterprises, the significance level alpha of 0.05 (Table 4). Based on the value of Cramer V correlation coefficients, can be said that it is a moderately strong association between qualitative variables analyzed.

Table 4: Results of Chi-square test ( $\chi 2$ test)- Events organizing

\begin{tabular}{|l|r|}
\hline Chi-square (Observed value) & 11.067 \\
Chi-square (Critical value) & 7.815 \\
DF & 3 \\
p-value & 0.011 \\
Alpha & 0.05 \\
\hline Cramer's V & 0.301 \\
\hline \multicolumn{2}{|c|}{ Source: own calculations, XLSTAT }
\end{tabular}

More detailed information on the events organizing can be seen in Table 5, where are the specific percentages of the analysed categories of enterprises. Analysed food companies with foreign participation organized events that are intended for the general public and the proportion of these events was at $80.65 \%$. On the other hand, the share of organized events companies with domestic capital for the general public stood at $48.35 \%$. Domestic enterprises organize more events compared with companies with foreign participation for its own customers respectively for business partners. Higher percentage of domestic enterprises do not organize events at all in comparison with the enterprises with foreign participation (21.98\%, respectively. $12.9 \%)$.

Table 5: Percentages of events organizing

\begin{tabular}{|l|r|r|r|r|r|}
\hline Business Category & $\begin{array}{c}\text { Yes, for the } \\
\text { general } \\
\text { public }\end{array}$ & $\begin{array}{c}\text { Yes, for our } \\
\text { customers }\end{array}$ & $\begin{array}{c}\text { Yeas, for } \\
\text { business } \\
\text { partners }\end{array}$ & $\begin{array}{c}\text { No, we do } \\
\text { not organize } \\
\text { events at all }\end{array}$ & \multicolumn{1}{c|}{ Total } \\
\hline $\begin{array}{l}\text { Enterprises with } \\
\text { Foreign Participation }\end{array}$ & 80.645 & 6.452 & 0.000 & 12.903 & $\mathbf{1 0 0}$ \\
\hline Domestic Enterprises & 48.352 & 15.385 & 14.286 & 21.978 & $\mathbf{1 0 0}$ \\
\hline Total & $\mathbf{5 6 . 5 5 7}$ & $\mathbf{1 3 . 1 1 5}$ & $\mathbf{1 0 . 6 5 6}$ & $\mathbf{1 9 . 6 7 2}$ & $\mathbf{1 0 0}$ \\
\hline
\end{tabular}

Source: own calculations, XLSTAT 
Kádeková, Z. - Nagyová, L. - Horská, E.

Table 6: Results of Chi-square test ( $\chi 2$ test)- frequency of events organizing

\begin{tabular}{|l|r|}
\hline Chi-square (Observed value) & 28.948 \\
Chi-square (Critical value) & 11.070 \\
DF & 5 \\
p-value & 0.0001 \\
Alpha & 0.05 \\
\hline Cramer's V & 0.487 \\
\hline
\end{tabular}

Source: own calculations, XLSTAT

For more information regarding the frequency of organizing events (Table 6) provides a Table 7, where are the percentages of events organizing frequencies.

Table 7: Percentages of events organizing frequencies

\begin{tabular}{|l|c|c|r|r|r|r|r|}
\hline \multicolumn{1}{|c|}{$\begin{array}{c}\text { Business } \\
\text { Category }\end{array}$} & $\begin{array}{c}\text { Once a } \\
\text { year }\end{array}$ & $\begin{array}{c}\text { Twice } \\
\text { a year }\end{array}$ & $\begin{array}{c}\text { More } \\
\text { than } \\
\text { twice a } \\
\text { year }\end{array}$ & $\begin{array}{c}\text { Less } \\
\text { than } \\
\text { twice a } \\
\text { year }\end{array}$ & $\begin{array}{c}\text { As needed } \\
\text { but more } \\
\text { than twice } \\
\text { a year }\end{array}$ & $\begin{array}{c}\text { We do not } \\
\text { organize } \\
\text { the events }\end{array}$ & Total \\
\hline $\begin{array}{l}\text { Enterprises } \\
\text { with foreign } \\
\text { Participation }\end{array}$ & 9.677 & 12.903 & 25.806 & 22.581 & 16.129 & 12.903 & $\mathbf{1 0 0}$ \\
\hline $\begin{array}{l}\text { Domestic } \\
\text { Enterprises }\end{array}$ & 45.055 & 16.484 & 5.495 & 4.396 & 6.593 & 21.978 & $\mathbf{1 0 0}$ \\
\hline Total & $\mathbf{3 6 . 0 6 6}$ & $\mathbf{1 5 . 5 7 4}$ & $\mathbf{1 0 . 6 5 6}$ & $\mathbf{9 . 0 1 6}$ & $\mathbf{9 . 0 1 6}$ & $\mathbf{1 9 . 6 7 2}$ & $\mathbf{1 0 0}$ \\
\hline
\end{tabular}

Source: own calculations, XLSTAT

The highest percentage of events organizing frequencies - more than twice a year are organized by companies with the foreign participation $(25.81 \%)$, in domestic enterprises is this percentage relatively low, namely $5.49 \%$. Companies with domestic participation frequently organize events regularly once a year (45.06\%). Regularly annually organize events only $9.68 \%$ of foreign companies. Overall, the analyzed companies organize regular events annually $(36.07 \%)$. These events are usually organized for Christmas celebrations, the anniversary of the founding of the company and other holidays.

When analyzing the type of organized events, there were not confirmed statistically significant differences between the analyzed categories of food businesses. These facts also documents the Table 8 , where the $\mathrm{p}$ value is greater than the level of reliability alpha 0.05 .

Table 8: Results of Chi-square test ( $\chi 2$ test)-Types of organized events

\begin{tabular}{|l|r|}
\hline Chi-square (Observed value) & 3.794 \\
\hline Chi-square (Critical value) & 11.070 \\
DF & 5 \\
p-value & 0.579 \\
Alpha & 0.05 \\
\hline \multicolumn{2}{|c|}{ Source: own calculations, XLSTAT }
\end{tabular}


Specific information on the types of organized events provides Table 9. Social events and activities are organized the most by both categories of the analyzed companies. This kind of events totals $72 \%$ share of all kinds of organized events. The second most numerous way of organized events were exhibitions, whose total share was $11 \%$.

Table 9: Percentages of types of organized events

\begin{tabular}{|l|r|r|r|r|r|r|r|}
\hline \multicolumn{1}{|c|}{$\begin{array}{c}\text { Business } \\
\text { category }\end{array}$} & $\begin{array}{c}\text { Professional } \\
\text { conferences }\end{array}$ & $\begin{array}{c}\text { Exhibi- } \\
\text { tions }\end{array}$ & $\begin{array}{c}\text { Dis- } \\
\text { cussions }\end{array}$ & $\begin{array}{c}\text { Open } \\
\text { Days }\end{array}$ & $\begin{array}{c}\text { Social } \\
\text { Events and } \\
\text { Activities }\end{array}$ & Others & Total \\
\hline $\begin{array}{l}\text { Enterprises } \\
\text { with Foreign } \\
\text { Participation }\end{array}$ & 3.571 & 3.571 & 0.000 & 10.714 & 78.571 & 3.571 & $\mathbf{1 0 0}$ \\
\hline $\begin{array}{l}\text { Domestic } \\
\text { Enterprises }\end{array}$ & 6.944 & 13.889 & 1.389 & 6.944 & 69.444 & 1.389 & $\mathbf{1 0 0}$ \\
\hline Total & $\mathbf{6 . 0 0 0}$ & $\mathbf{1 1 . 0 0 0}$ & $\mathbf{1 . 0 0 0}$ & $\mathbf{8 . 0 0 0}$ & $\mathbf{7 2 . 0 0 0}$ & $\mathbf{2 . 0 0 0}$ & $\mathbf{1 0 0}$ \\
\hline
\end{tabular}

Source: own calculations, XLSTAT

In previous analyzes have been found statistically significant differences in the perception of the benefits from using events for the entire reference set of analyzed food companies. There was subsequently performed an analysis of perception of the benefits from events organizing for each category of business.

\section{Analysis of the Preferred Media in Domestic Enterprises and Enterprises with Foreign Participation}

When analyzing the type of preferred media were found statistically significant differences between the analyzed categories of enterprises. Table 10 shows the results of the $\chi^{2}$ test, which rejects the null hypothesis of independence preferred media type, since the $p$ value is less than alpha of 0.05 . In this case, we can talk about moderate dependence.

Table 10: Results of Chi-square test $(\chi 2$ test)-Types of preferred media

\begin{tabular}{|l|r|}
\hline Chi-square (Observed value) & 19.621 \\
Chi-square (Critical value) & 3.841 \\
DF & 1 \\
p-value & 0.0001 \\
Alpha & 0.05 \\
\hline Cramer's V & 0.422 \\
\hline \multicolumn{2}{|c|}{ Source: own calculations, XLSTAT }
\end{tabular}

Enterprises with foreign participation prefer mostly nationwide media, while domestic enterprises prefer regional media. Overall, the share of using the nationwide media is higher than the share of regional (Table 11). 
Kádeková, Z. - Nagyová, L. - Horská, E.

Table 11: Percentages of Types of Preferred Media

\begin{tabular}{|l|r|r|r|}
\hline \multicolumn{1}{|c|}{ Business category } & \multicolumn{1}{c|}{ Regional } & \multicolumn{1}{c|}{ Nationwide } & \multicolumn{1}{c|}{ Total } \\
\hline Enterprises with Foreign Participation & 9.677 & 90.323 & $\mathbf{1 0 0}$ \\
\hline Domestic Enterprises & 57.778 & 42.222 & $\mathbf{1 0 0}$ \\
\hline Total & $\mathbf{4 5 . 4 5 5}$ & $\mathbf{5 4 . 5 4 5}$ & $\mathbf{1 0 0}$ \\
\hline
\end{tabular}

Source: own calculations, XLSTAT

\section{Conclusion}

Concerns about social and environmental issues provide opportunities for brands to connect with their consumers at a deeper level and, in doing so, gain competitive and sales advantage. Pioneering companies have proved that moving towards more sustainable marketing practices can be a shrewd business move. For many, operating in an ethically and environmentally responsible way is proving to be a cost-effective hit with customers. There is a need to communicate each step connected with this issues with customers. The way of doing this is using PR as the main tool of communication policy working for 3P - Planet, People and Profit. In Slovakia, there are TOP 10 leading PR stating that their most important clients from the agribusiness are Nestle Slovakia, Unilever Slovakia, Danone Slovakia, Coca-Cola Slovakia, Wrigley, Slovakia Chips, Dr. Oetker, Heineken, Kofola, Hubert J.E., Slovakia Chips, Hyza, McCain, Penam, Topvar, Becherovka, Pepsi-Cola SR, Hame Slovakia, Teekane.

For the companies is necessary to realize that the reputation can't be built on what companies are going to do, the most important is what they are doing now and how is the communication with customers and public. By using PR tools is reaching attention of mentioned groups much easier. The business world of today is extremely competitive. Companies need to have an edge that makes them stand out from the crowd, something that makes them more appealing and interesting to both the public and the media. The public are the buyers of the product or services and the media are responsible for selling it. Public Relations (often referred to as PR) includes activities intended to promote understanding of the company or product, service . Through PR activities may be influenced the public opinion by delivering messages without incurring direct media costs.

The most popular PR activity is Events organizing, more than twice a year are organized by companies with the foreign participation. Enterprises with foreign participation prefer mostly nationwide media to promote, while domestic enterprises prefer regional media. PR also helps the company to achieve its full potential and provide feedback from the public. This usually takes the form of research regarding what areas the public prefers or does not prefer. 


\section{References}

1. Ábelová, V.; Kádeková, Z. (2011): Vnímanie reklamy potravinárskych produktov In New Trends in Marketing Communication. Proceedings from International Scientific Conference New Trends in Marketing. Trnava: FMK UCM, pp. 60-77.

2. Belz, F-M. (2005): Sustainability Marketing: Blueprint of a Research Agenda. In Discussion Paper no. 1, Marketing and Management in the Food Industry, 2005. Freising,Technische Universität München, pp. 21-22.

3. Belz, F-M.; Birte, K. (2005): Nachhaltigkeits-Marketing: Konzeptionelle Grundlagen undempirische Ergebnisse (Sustainability Marketing: Conceptual Basics and Empirical Findings). In Belz and Bilharz (eds): Nachhaltigkeits-Marketing in Theorie und Praxis (Sustainability Marketing in Theory and Practise), pp. 19-39.

4. Belz, F-M.; Birte, K. (2005): Strategic and InstrumentalSustainability Marketing in the Western European Food Processing Industry: Conceptual Framework and Hypotheses . CRR Conference 2005. (online). 2013. (cit. 2013-03-29). Dostupné na: http://www.crrconference.org/previousconferences/bse2005/proceedings/frankmartinbelzan dbirtekarstens.html

5. Bennett, P. L. (2013): Telling Stories is great for sustainability marketing. In Guardian. (online). 2005. (cit. 2013-03-28). Dostupné na: http://www.guardian.co.uk/ sustainablebusiness/blog/telling-positive-stories-sustainability-marketing

6. Business Register. Ministry of Justice of the Slovak Republic. (online). 2013. (cit. 2013-0328). Dostupné na: http://www.orsr.sk

7. Christopher, M.; Payne, A.; Ballantyne, D. (1991): Relationship Marketing: Bringing quality, customer service and marketing together. Oxford: Butterworth-Heinemann, pp. 159-166.

8. CSR Europe. The European Business Network for CSR. 2013. Sustainable Marketing. (online). 2013. (cit. 2013-03-29). Dostupné na: http://www.csreurope.org/pages/en/ sustainable_marketing.html

9. Gašparíková, V.; Nagyová, L. (2010): Efficiency of website promotion in agricultural resort. In Enterprise and competitive environment. Conference proceeding. Brno, Mendel University in Brno, 2010. pp. 204-215.

10. Horská, E. et al. (2011): European studies on intercultural dimension of international business: Marketing and managerial consequences. Nitra, Slovak University of Agriculture in Nitra, $203 \mathrm{p}$.

11. Horská, E.; Nagyová, L'; Rovný, P. et al. (2010): Merchandising and event marketing for agrifood products. Nitra: SUA, $329 \mathrm{p}$.

12. Horská, E.; Ürgeová, J. (2009): Preferences and Dilemmas: Food quality and country of origin image perception in some central European countries. In Науқоьий Вісһиқ Націоһa Льһого Yhibepcutety Біоресурсіb I Природокорисtybahhя Үкраiһи (Scientific Messenger of National University of Bioresources and Environment management of Ukraine). Vol. 142, Part 1. Kuib (Kyjev), pp. 58-63.

13. Kleinová, K.; Ürgeová, J. (2011): Country Image and Branding of Slovakia. In Zeszyty Naukowe Szkoły Głownej Gospodarstwa Wiejskiego w Warszawie - Polityki Europejskie, Finanse i Marketing. Nr 5, č. 54, pp. 50-59.

14. Kotler, P.; Armstrong, G. (2004): Principles of Marketing. 10th edition. New Jersey: Prentice Hall, 768 p.

15. Kretter, A. et al. (2010): Marketing. 4th Edition. Nitra, SUA, 287 p. 
16. Kubicová, L. (2007): Income situation and purchasing behaviour of the inhabitants on the food market in the Slovak Republic. In Proceedings of the international scientific conference Agrarian Perspectives XVI. European trends in agriculture and rural development. Prague, CZU, pp. 1-9.

17. Kubicová, L'.; Kádeková, Z. (2011): Marketing strategy of the new product introduction on the market. In Polityki europejskie, Vol. 54, No. 5. pp. 78-90.

18. Neopublic Porter Novelli (APR SR, IPRA). 2013. (online). 2013. (cit. 2013-03-28). Dostupné na: http://www.asociaciapr.sk.

19. Ries, A.; Ries, L. (2009): The Fall of Advertising and the Rise of PR. New York: Harper Collins Publishers, $320 \mathrm{p}$.

20. Rochte, M. (2009): Opportunity Sustainability. (online). 2013. (cit. 2013-03-29). Dostupné na: http://www.opportunitysustainability.com/?p=323.

21. Statistical Office of the Slovak Republic (2013): Agriculture: SO SR. Agricultural Services: RADELA, s.r.o. Bratislava. Food Enterprises: CD MP SR (PROD 3-04, Vol. 2-01), Radela, s.r.o.

22. Strategies. HN online. 2013. (online). 2013. (cit. 2013-03-25). Dostupné na: http://strategie.hnonline.sk.

23. Wells, W.; Burnett, J.; Moriarty, S. (2002): Advertising: Principle and Practice. New Jersey: Prentice Hall, 2002. 312 p. 